\title{
A Preliminary Study of Ammonia Production by Coryne- bacterium renale and some other Pathogenic Bacteria
}

\author{
By R. LOVELL AND D. G. HARVEY \\ Royal Veterinary College, London
}

SUMMARY: Urease is a constituent enzyme of Corynebacterium renale and appears to account for the bulk of its ammonia production. C. renale also contains an arginase and some amino-acid deaminases, but the former has not been fully characterized. Bovine urine supports the growth of a small inoculum of $C$. renale for a limited time but after growth has reached a maximum it diminishes rapidly and the ammonia and $\mathrm{pH}$ values increase. $C$. renale also contains uricase but its precise significance has not yet been determined.

Of the other bacteria studied, C. ovis has urease activity similar to $C$. renale, and $C$. pyogenes a stronger initial arginase. $C$. equi contains no appreciable urease or arginase, although it tends to form ammonia from glutamine.

Corynebacterium renale is the cause of a specific cystitis and pyelonephritis in cattle; the lesions in natural infections in cattle and in experimental infections in mice and rabbits after intravenous inoculation are localized in the medulla of the kidney (Lovell, 1946; Lovell \& Cotchin, 1946; Feenstra, Thorp \& Gray, 1949). This selective localization may, in part, be explained by the metabolic and enzyme activities of the organism, and a study of its ammonia-producing capacity was made because of the old observation that $C$. renale produces ammonia when grown in urine. A preliminary test was made to confirm this by growing a strain of $C$. renale in bovine urine and in peptone water containing $1 \%(w / v)$. urea. After $48 \mathrm{hr}$. incubation at $37^{\circ}$ flasks of uninoculated media and those in which the organism had been grown were filtered through Seitz filters and the filtrates examined for free ammonia, urea and creatine. The results are given in Table 1, and show that in bovine urine and in a urea medium $C$. renale breaks down the urea with the formation of free ammonia. The creatine content of the urine remained constant, but largely diminished in the urea medium probably because of the peptone present.

The ammonia-producing capacity of $C$. renale was therefore examined and a few comparative tests made with C. ovis, C. equi, C. pyogenes and Bacterium coli.

The methods employed were:

\section{METHODS}

(a) Washed suspensions of $C$. renale prepared from growth on agar slopes were seeded into sterile urine, peptone water containing $1 \%$ urea, hydrolysed peptone water and peptone water. The urine was sterilized by Seitz-filtration, and the hydrolysed peptone was prepared from a stock solution which consisted of a mixture of $100 \mathrm{~g}$. of Bactopeptone and $300 \mathrm{ml}$. of conc. hydrochloric acid (A.R.) which had been boiled under a reflux condenser for $48 \mathrm{hr}$. after which most of the acid had been removed by vacuum distillation; the solution was neutralized to $\mathrm{pH} 7$ by $\mathrm{NaOH}$, diluted to give approximately $1 \% \mathrm{NaCl}$; 
L-tryptophan was added to give a concentration equivalent to $1 \mathrm{~g}$. for every $100 \mathrm{~g}$. of peptone originally used. After inoculation all cultures were incubated at $87^{\circ}$ and periodical examinations made. The number of living bacteria $/ \mathrm{ml}$. was determined by plate counts on nutrient agar and estimations made of the ammonia and urea contents.

Table 1. Content of urea, $\mathrm{NH}_{3}$ and creatine (in g./100 ml.) of filtrates of urine and urea medium before and after growth of Corynebacterium renale at $37^{\circ}$ for $48 \mathrm{hr}$.

\begin{tabular}{|c|c|c|c|c|}
\hline & Bov & e urine & Ure & medium \\
\hline & Control & After growth & Control & After growth \\
\hline $\begin{array}{l}\text { Urea } \\
\text { Free ammonia } \\
\text { Creatine. }\end{array}$ & $\begin{array}{l}\mathbf{2 \cdot 8 2} \\
\mathbf{N i l} \\
0 \cdot 186\end{array}$ & \begin{tabular}{l|l|}
$0 \cdot 12$ \\
$1 \cdot 309$ \\
$0 \cdot 186$
\end{tabular} & $\begin{array}{l}0 \cdot 72 \\
\text { Nil } \\
0 \cdot 21\end{array}$ & $\begin{array}{l}\text { Nil } \\
0 \cdot 289 \\
0 \cdot 0232\end{array}$ \\
\hline
\end{tabular}

(b) A cell-free extract of $C$. renale was prepared by growing large quantities of $C$. renale on nutrient agar for $48 \mathrm{hr}$.; the growth was collected, washed with saline and 10 vol. of cold acetone added to 1 vol. of thick washed suspension; the mixture was stirred with a glass rod and filtered through paper and the filter-paper washed with more acetone. The deposit was scraped off the filterpaper, dried over calcium chloride and then ground to a fine powder. Samples of the powder were added to different nitrogenous substrates in a buffered solution consisting of a mixture of $6 \mathrm{ml} .0 \cdot 1 \mathrm{M}-\mathrm{NaHCO}_{3}$ and $12 \mathrm{ml} .0 \cdot 1 \mathrm{M}-$ $\mathrm{KH}_{2} \mathrm{PO}_{4}$, the volume of which was made up to $40 \mathrm{ml}$. with distilled water; when using tyrosine, cystine and uric acid the concentration of $\mathrm{KH}_{2} \mathrm{PO}_{4}$ and $\mathrm{NaHCO}_{3}$ was doubled. In order to avoid confusion between possible D- and L-deaminases DL-amino-acids were used wherever possible. Each individual constituent was weighed to give a final concentration of $15 \mathrm{~mm}$. When mixtures of the nitrogenous substrates were used $1 \mathrm{ml}$. quantities of each substrate was taken as required and $5 \mathrm{ml}$. of the total taken for estimation purposes.

The ammonia was estimated by either micro- or macro-methods with steam distillation (Kjeldahl) or aeration (Van Slyke). For the nitrogenous substrates and their mixtures the following procedure was adopted. Five ml. of the stock solution was mixed with $5 \mathrm{ml}$. of an aqueous suspension of the cell-free extract of $C$. renale made by adding $150 \mathrm{mg}$. of the powder to $60 \mathrm{ml}$. of distilled water; this was incubated $4 \mathrm{hr}$. at $37-40^{\circ}$; toluene was added as a preservative. After incubation, the solution was treated with $5 \mathrm{ml}$. of saturated $\mathrm{K}_{2} \mathrm{CO}_{3}$ solution in a modified micro-Kjeldahl apparatus and the ammonia distilled into $5 \mathrm{ml}$. of $2 \%$ boric acid + bromocresol blue and the final solution titrated with $0.01 \mathrm{~N}$ $\mathrm{H}_{2} \mathrm{SO}_{4}$. The urea titrations were made by the Van Slyke urease method; the creatine and creatinine by Folin's method as modified by Cole (1933) and his modification of Benedict's method was used for the titration of uric acid. The allantoin titration was that of Larson as described by Hawk, Oser \& Summerson (1947). 


\section{RESULTS}

Growth of Corynebacterium renale in bovine urine and urea medium

The results obtained by growth of $C$. renale in bovine urine are shown in Figs. 1 and 2. In the first experiment (Fig. 1) the initial inoculum was small, about 1500 viable bacteria $/ \mathrm{ml}$; the number increased to $1.5 \times 10^{6}$ at $48 \mathrm{hr}$. and then diminished till after 6 days' incubation only $100 \mathrm{organisms} / \mathrm{ml}$. were viable. This coincided with a decrease in urea, from 1.25 to $0.25 \mathrm{~g} . / 100 \mathrm{ml}$. at the third day, whilst the ammonia content increased to a little over $0.5 \mathrm{~g} . /$ $100 \mathrm{ml}$. during the same period. The second experiment (Fig. 2) shows the results with a large inoculum. The initial viable count of 162,000 organisms $/ \mathrm{ml}$. fell almost in a straight line to zero; in this sample of urine the urea content was $2 \cdot 65 \mathrm{~g}$. $/ \mathrm{ml}$. which fell to $2 \mathrm{~g}$. $/ \mathrm{ml}$. by the seventh day; there was a corresponding increase in ammonia.

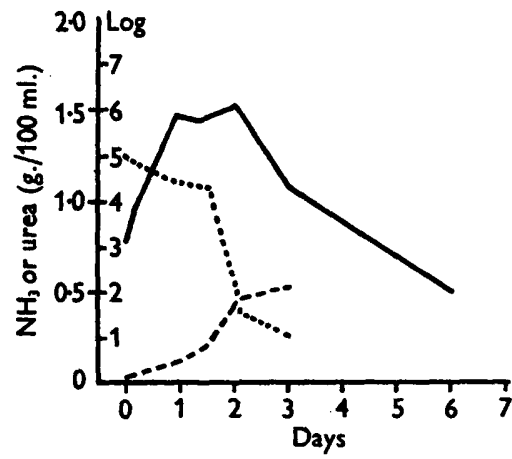

Fig. 1

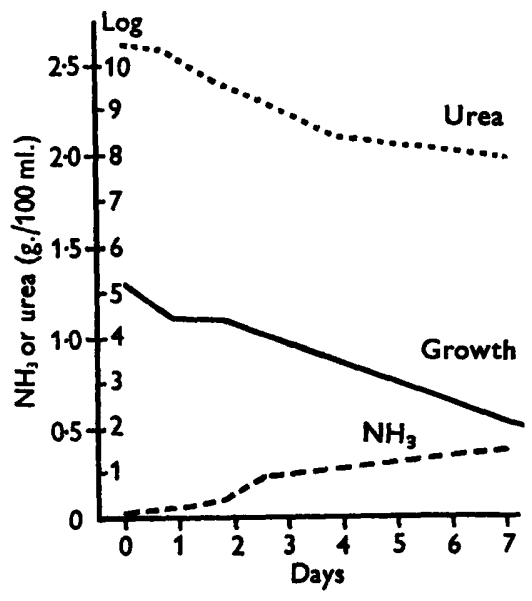

Fig. 2

Fig. 1. Urease activity and growth of $C$. renale in bovine urine. - Logarithmic count of growth; ...... urea in $\mathrm{g} . / 100 \mathrm{ml} . ;-\ldots . .-\mathrm{NH}_{8}$ in $\mathrm{g} . / 100 \mathrm{ml}$.

Fig. 2. Urease activity and growth of $C$. renale in bovine urine. - Logarithmic count of growth; ...... ures in $\mathrm{g} . / 100 \mathrm{ml} . ; . . . .-\mathrm{NH}_{8}$ in $\mathrm{g} . / 100 \mathrm{ml}$.

Whether the initial inoculum of $C$. renale is large or small there is in bovine urine a steady though not always a rapid disappearance of the urea with a corresponding increase of ammonia concentration and $\mathrm{pH}$ value, the latter reaching $9 \cdot 5$.

In peptone water containing $1 \%(\mathrm{w} / \mathrm{v})$ urea similar results are obtained (Fig. 3). With an inoculum of 140,000 viable organisms $/ \mathrm{ml}$. there was a steady decrease in viable organisms, a fall in the urea content within $72 \mathrm{hr}$. and a corresponding increase in ammonia.

A different picture emerged when $C$. renale was grown in peptone water or in acid-hydrolysed peptone water (Fig. 4). In the former medium an inoculum approximating to that used in the urea medium grew and reached its peak at about $48 \mathrm{hr}$., thereafter falling gradually. Small amounts of ammonia were 
present, from 13 to $30 \mathrm{mg}$. $/ 100 \mathrm{ml}$. In the acid-hydrolysed peptone water the viable organisms were rapidly killed and none were recovered after $48 \mathrm{hr}$. incubation. The ammonia content was irregular, varying from 6 to $23 \mathrm{mg}$./ $100 \mathrm{ml}$.

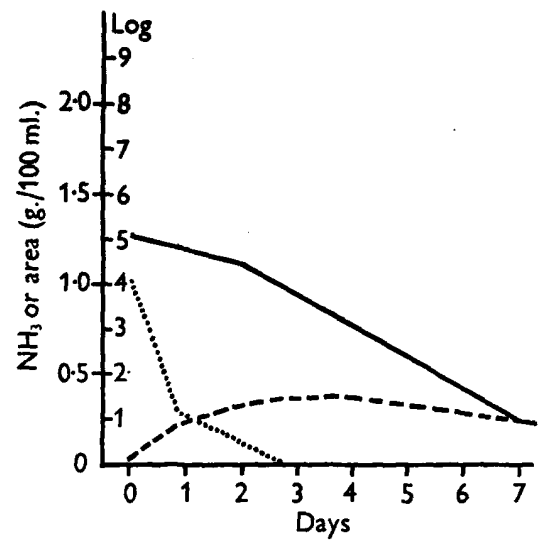

Fig. 3

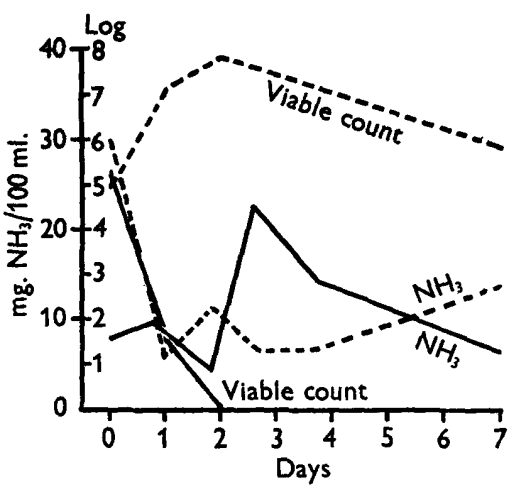

Fig. 4

Fig. 3. Urease activity and growth of C. renale in peptone water medium containing $1 \%$ urea. Logarithmic count of growth; $\ldots . .$. urea in $\mathrm{g} . / 100 \mathrm{ml}$; $\ldots \ldots \mathrm{NH}_{3}$ in g./100 ml.

Fig. 4. $\mathrm{NH}_{3}$ production and growth of $\mathrm{C}$. renale in peptone water and in acid-hydrolysed peptone water. -.... Peptone water; acid-hydrolysed peptone water.

Incubation of cell-free extract of Corynebacterium renale in nitrogenous substrates

The results obtained after incubation of the cell-free extract of $C$. renale in different nitrogenous substrates are shown in Table 2. They are compared with those obtained with similar products from C. equi, C. ovis, C. pyogenes and Bact. coli. Ammonia production by $C$. renale, although small, occurred with most of the substrates, the one exception being urea, which was rapidly and completely broken down. Prolonged incubation appeared to favour an arginase activity but beyond that ammonia production was slight. $C$. ovis also has urease, but $C$. pyogenes and Bact. coli have none; there is some evidence of an arginase of $C$. pyogenes but $C$. equi possesses neither urease nor arginase, it appears to break down $(\mathrm{L}+$ )-glutamine. Of the five organisms studied, C. equi and Bact. coli produced least ammonia when their cell-free extracts were incubated with a mixture of all the nitrogenous substances. This is difficult to reconcile with the results obtained when the strains were grown on the media described by Christensen (1946); in this medium, C. renale, C. ovis and C. equi gave evidence of urease activity, $C$. pyogenes gave a slight change in colour and Bact. coli failed to produce this change. When the phenol red was replaced by thymol blue (0.012 g./1.), positive reactions occurred with $C$. renale and C. equi and none with $C$. ovis, $C$. pyogenes and Bact. coli. In both media C. renale gave rapid and intense reactions. 
Table 2. The ammonia production (as $\mu$ g. $\mathrm{NH}_{3} / \mathrm{mg}$. dry weight of cell-free enzyme preparation) after $4 \mathrm{hr}$. incubation with various substrates which were single or mixtures of nitrogenous compounds

( $a=$ results obtained with individual nitrogenous compounds; $b, c$ and $d=$ results obtained when different mixtures of compounds were used; . = no estimation made with this individual compound. All the amino-acids were DL except tyrosine, cystine, glutamine and arginine which were $\mathrm{L}$. Cell-free extracts, when incubated in the buffer solution alone, gave slight traces of ammonia only.)

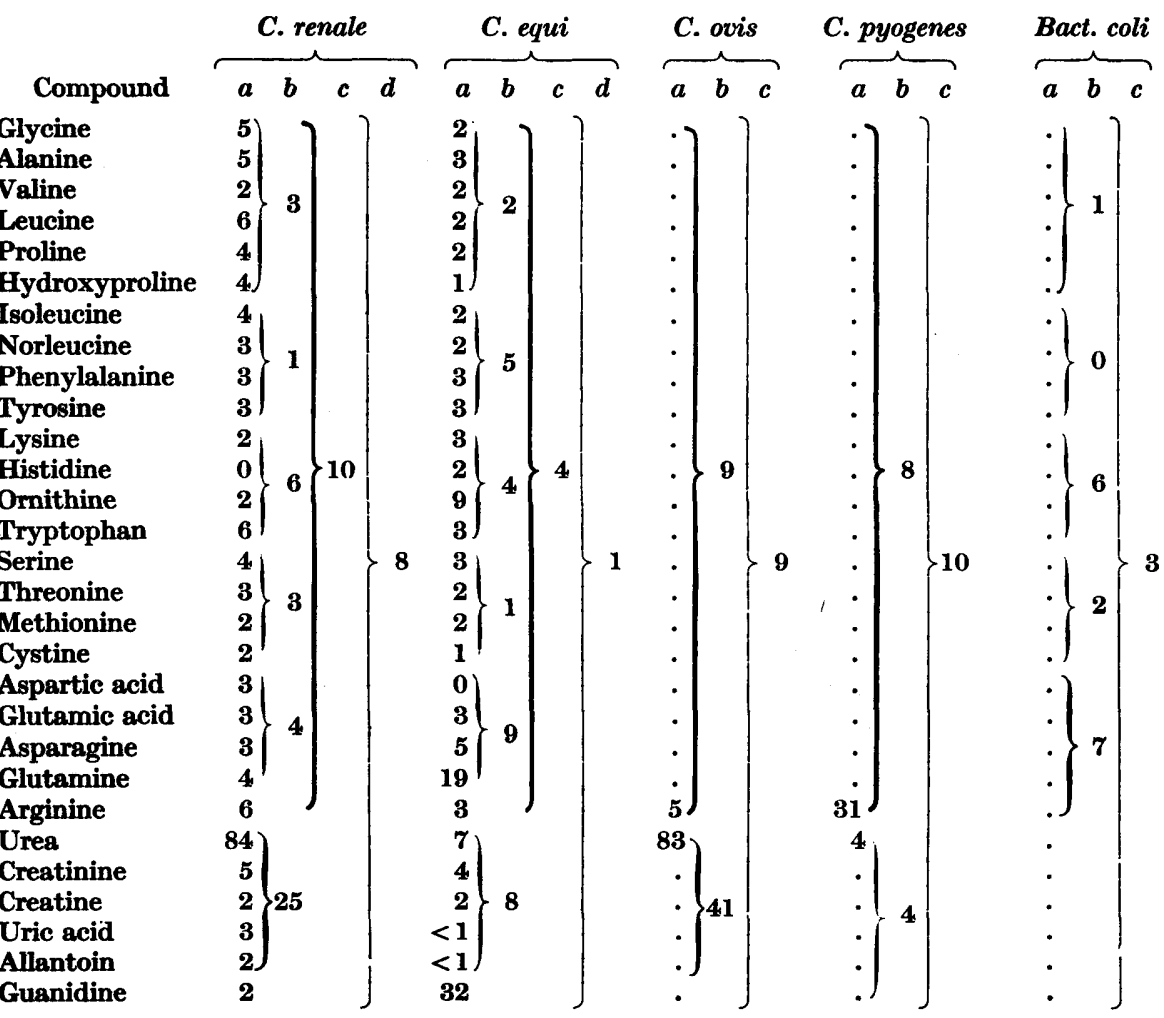

The arginase activity was studied by incubating $25 \mathrm{mg}$. of cell-free extract in a solution containing $50 \mathrm{ml}$. of a solution of $0.05 \mathrm{M}$ arginine, $5 \mathrm{ml}$. of $0.6 \%$ $\mathrm{KH}_{2} \mathrm{PO}_{4}$ and $0.45 \mathrm{ml}$. of $0.01 \mathrm{M}-\mathrm{MnSO}_{4}$, and water to $100 \mathrm{ml}$; t toluene was added as preservative. A control flask omitting the $\mathrm{MnSO}_{4}$ solution was included and the mixtures were incubated at $37^{\circ}$ for 7 days. With the $C$. renale extract (Fig. 5) there was a steady increase in ammonia production, enhanced by the $\mathrm{MnSO}_{4}$. Comparable extracts from C. equi and Bact. coli produced little ammonia, with no significant increase by $\mathrm{MnSO}_{4}$. The arginase activity of C. renale was further demonstrated by the recovery of ornithuric acid after 3 days' incubation. This was effected by boiling the opalescent solution with 2-3 g. of kieselguhr for 30 sec., filtering and concentrating in vacuo to $25-30 \mathrm{ml}$.; the concentrate was treated with $1 \mathrm{ml}$. benzoyl chloride and excess $\mathrm{NaOH}$, acidified with $5 \%$ sulphuric acid, shaken with $5 \times 20 \mathrm{ml}$. of ether and allowed 
to cool. Impure ornithuric acid (dibenzoylornithine) was filtered off and recrystallized from dilute aqueous ethanol in colourless needles, M.P. 187-188 (uncorr.). Hills (1940) gave the melting-point as $182^{\circ}$ and quoted references giving a range of $182-189^{\circ}$. The yield from $1.052 \mathrm{~g}$. of $(\mathrm{L}+)$-arginine was $500 \mathrm{mg}$. (55\% of theoretical). The once-recrystallized sample contained $7 \cdot 2 \% \mathrm{~N} ; \mathrm{C}_{10} \mathrm{H}_{20} \mathrm{O}_{4} \mathrm{~N}_{2}$ requires $8 \cdot 2 \% \mathrm{~N}$. Yellow-orange crystalline precipitates

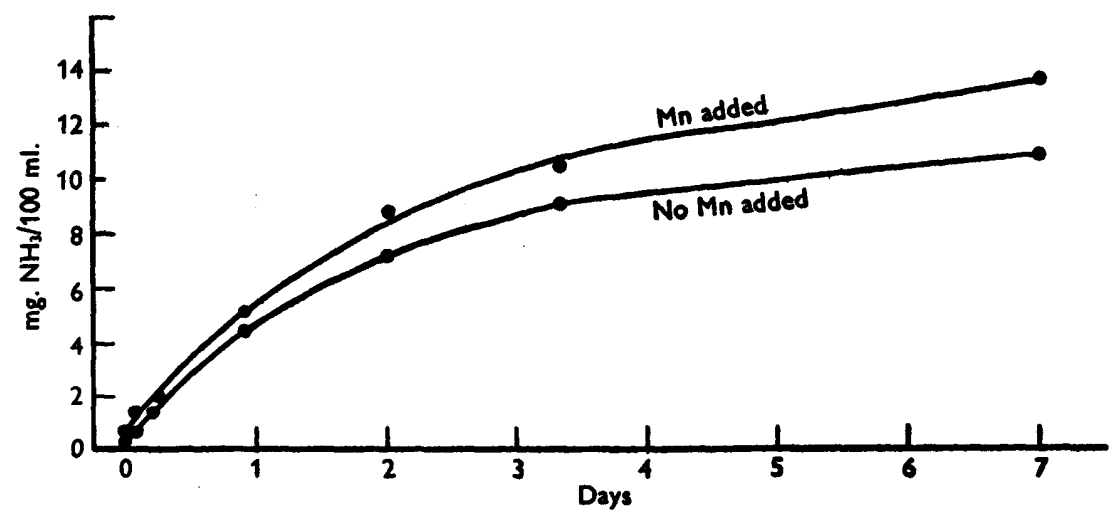

Fig. 5. Decomposition of arginine and production of $\mathrm{NH}_{\mathrm{a}}$ by cell-free extract of $C$. renale with and without added manganese.

were obtained from the $C$. equi and Bact. coli flasks when they were clarified and treated with $5 \%$ flavianic acid. These precipitates decomposed at 260-270 with no sharp melting-points. The nitrogen analysis figures indicate that these substances were probably mixtures; Bact. coli has already been shown to possess an arginine decarboxylase activity giving rise to agmatine (Gale, $1940 a, b)$.

\section{The breakdown of nitrogenous constituents in human urine} by cell-free extracts

A sample of human urine at $\mathrm{pH} 7$ was divided into portions of $50 \mathrm{ml}$. and to three of them were added $25 \mathrm{mg}$. of the cell-free extracts of C. renale, C. equi and Bact. coli respectively. After $40 \mathrm{hr}$. incubation at $37^{\circ}$ the main nitrogenous constituents were estimated in all four samples (Table 8 ).

Table 3. Nitrogenous constituents of human urine after incubation with cell-free extracts of Corynebacterium renale, $\mathrm{C}$. equi and Bacterium coli

\begin{tabular}{|c|c|c|c|c|}
\hline & \multirow{2}{*}{$\begin{array}{l}\text { Actual values } \\
\text { of control } \\
\text { sample } \\
\text { (mg./100 ml.) }\end{array}$} & \multicolumn{3}{|c|}{$\begin{array}{l}\text { Percentage recovery when incubated with } \\
\text { cell-free extracts of }\end{array}$} \\
\hline & & C. renale & C. equi & Bact. coli \\
\hline $\mathbf{N H}_{8}$ & $42 \cdot 5$ & 1700 & 80 & 40 \\
\hline Urea & 1165 & 5 & 100 & - \\
\hline Creatinine & $97 \cdot 5$ & $99-100$ & $99-100$ & $99-100$ \\
\hline Creatine & $23 \cdot 7$ & $99-100$ & $99-100$ & $99-100$ \\
\hline Uric acid & $10 \cdot \theta$ & 50 & $99-100$ & 99 \\
\hline Allantoin & $\mathbf{3} \cdot \mathbf{1}$ & 155 & $99-100$ & 100 \\
\hline & $7 \cdot 0$ & $8 \cdot 8$ & $7 \cdot 1$ & $7 \cdot 1$ \\
\hline
\end{tabular}


The cell-free extract of $C$. renale attacked urea with a corresponding increase in the ammonia content. There was also a fall in uric acid with an increase in allantoin. Only slight changes occurred with extracts of $C$. equi and Bact. coli.

\section{DISCUSSION}

The ability of $C$. renale to form ammonia from various nitrogenous substrates undoubtedly lies in its urease activity. In common with the other bacteria studied it forms ammonia from a series of amino-acids, but in this respect its activity is slight. Proteolytic activity is also small and any ammonia produced by this means probably comes from the hydrolysis of amide nitrogen or by a primary proteolytic breakdown of the molecule followed by deaminase activity. This may be compared with the protease isolated from a streptococcus by Stevens \& West (1922) and with the action of $C$. equi on glutamine.

We have not yet determined whether the arginase possessed by $C$. renale is a monohydrolase or dihydrolase. One practical difficulty is the wide $\mathbf{p H}$ range of the urease present, which we tentatively suggest is 5-9. If the arginase activity is optimal at $\mathrm{pH} 9 \pm 0.5$ (Folley \& Greenbaum (1948) suggest it is 9.45$)$, then it may be possible to isolate an intermediate product such as urea which may be formed if the arginase is a normal monohydrolase type (Hills, 1940). There is no evidence that $C$. renale forms urea as an intermediate from compounds containing the $=\mathrm{N}-\mathrm{C}-\mathrm{N}=$ linkage, such as creatine, creatinine, uric acid and allantoin. It is therefore unlike C. ureafaciens (Krebs \& Eggleston, 1939). The only other enzyme activity concerned with urinary nitrogenous products, other than amino-acids, is uricase, an enzyme whose activity would be enhanced by the presence of the urea/urease system. Uricase is present in $C$. renale in sufficient amount to cause the disappearance of $50 \%$ of uric acid in human urine at $\mathrm{pH} 7$ after $\mathbf{4 0} \mathrm{hr}$. incubation. Further study of this isolated fact might reveal a linkage between the tissue of the host and the metabolic activities of the particular pathogen (Fildes, 1934-5; Knight, 1936). The activity of $C$. renale may be bound up with enzyme systems other than those which produce ammonia. Gale $(1940 a, b)$ showed that Bact. coli possesses a decarboxylase capable of converting arginine into agmatine, and although there is no evidence of agmatine formation by $C$. renale, other natural bases may be revealed which are harmful to the kidney tissue.

The differences in the growth curves in bovine urine from small and large inocula may be due to the rapid increase in ammonia production and $\mathrm{pH}$ value, produced by the larger concentration of urease. It is useless to speculate with a medium such as urine, as each sample is different, and it may be that any essential metabolites present are inadequate for small inocula and the growth thereby influenced in that way.

It is hoped to continue the study of the enzyme characteristics of $C$. renale, and one plan consists of varying the constituent nutrients. Hills (1940) noted that the relative concentrations of arginase and urease were sometimes reversed when growing staphylococci on special media. The main object is a study of the factors and conditions responsible for the localization and 
multiplication of $C$. renale in the kidney medulla; it may lead to a fuller understanding of its pathogenesis and of the general problem of tissue localization.

We are indebted to Prof. C. Rimington and Dr G. Brownlee for gifts of some amino-acids and derivatives and to Messrs E. Langford and V. Drummond for valuable technical assistance.

\section{REFERENCES}

Christensen, W. B. (1946). Urea decomposition as a means of differentiating Proteus and Paracolon cultures from each other and from Salmonella and Shigella types. J. Bact. 52, 461.

Cone, S. W. (1933). Practical physiological chemistry, 9th ed. Cambridge: Heffer and Sons.

Feenstra, E. S., Thorp Jr., F. \& Gray, M. L. (1949). Pathogenicity of Corynebacterium renale for rabbits. Amer. J. vet. Res. $10,12$.

Findes, P. (1934-5). Some medical and other aspects of bacterial chemistry. Proc. R. Soc. Med. $28,79$.

Folley, S. J. \& Greenbaum, A. L. (1948). Determination of the arginase activities of homogenates of liver and mammary gland; effects of $\mathrm{pH}$ and substrate concentration and especially of activation by divalent metal ions. Biochem. J. 43, 537 .

GaLe, E. F. $(1940 a)$. The production of amines by bacteria. I. The decarboxylation of amino-acids by strains of Bacterium coli. Biochem. J. 34, 392.

GaIE, E. F. (1940 b). The production of amines by bacteria. III. The production of putrescine from $\mathrm{L}-(+)$-arginine by Bacterium coli in symbiosis with Streptococcus faecalis. Biochem. J. 34, 853.

Hawk, P. B., Oser, B. L. \& Summerson, W. H. (1947). Practical physiological chemistry, 12th ed. York, Pa., U.S.A.: Mapel Press Company.

Hrus, G. M. (1940). Ammonia production by pathogenic bacteria. Biochem. J. 34, 1057.

KnIGht, B. C. G. J. (1936). Bacterial nutrition. Spec. Rep. Ser. med. Res. Coun., Lond., no. 210.

Krebs, H. A. \& Eggleston, L. V. (1939). Bacterial urea formation (metabolism of Corynebacterium ureafaciens). Enzymologia, 7, 310.

Lovels, R. (1946). Studies on Corynebacterium renale. I. A systematic study of a number of strains. J. comp. Path. 56, 196.

Lovell, R. \& Cotchin, E. (1946). Studies on Corynebacterium renale. II. The experimental pathogenicity for mice. J. comp. Path. 56, 205.

Stevens, F. A. \& West, R. (1922). The peptase, lipase and invertase of hemolytic Streptococcus. J. exp. Med. 35, 823. 